\title{
Exploration of Zika Virus Travel-related Transmission and a Review of Travel Advice to Minimise Health Risks to UK Travellers
}

\author{
Vincent Icheku $^{1, *}$, Chinelo Icheku ${ }^{2}$ \\ ${ }^{1}$ School of Health and Social Care, London South Bank University, UK \\ ${ }^{2}$ NHS Jenner Health Centre, UK
}

Copyright $\bigcirc 2016$ by authors, all rights reserved. Authors agree that this article remains permanently open access under the terms of the Creative Commons Attribution License 4.0 International License

\begin{abstract}
The World Health Organization (WHO) on 1 February 2016 declared the Zika virus outbreak is a global public health emergency. Zika virus is thought to have led to more than 11,000 deaths and nearly 4,000 cases of microcephaly in Brazil since the start of the outbreak in May 2015. WHO predicted that, in 2016, as many as four million people may be infected with the virus. [1] Health experts have warned that the risk of transmitting Zika virus in the United Kingdom (UK) is very high because South America has become an increasingly popular tourist destination for UK travellers. [2] Given the declaration of Zika virus outbreak as a global public health emergency, this study explores Zika virus travel-related transmission and review current travel advice to minimise health risks to UK travellers. The evidence from our initial literature review showed that there is a paucity of research information on the recent Zika virus outbreak. Thus, the evidence used in this study was gathered from surveillance reports published by the European Centre for Disease Prevention and Control (ECDC), the United States Centers for Disease Control and Prevention (CDC) and the World Health Organization (WHO). Public Health England (PHE), Fitfortravel (NHS Scotland) and NHS Choices reports were reviewed for Zika virus outbreak alerts and travel advice. The study finds that Zika virus, which originated in East Africa, is now transmitted in South and North American countries and the Caribbean islands through travel and, to prevent the disease epidemic in the UK, health care professionals are required by PHE to offer advice to travellers to and from the Zika-affected countries. [3] As travel advice is likely to change as more information becomes available, we recommend that professionals supplying this service should be checking on the National Travel Health Network and Centre $(\mathrm{NaTHNaC})$ website to stay abreast of the latest Zika virus updates.
\end{abstract}

Keywords Aedes-aegypti Mosquitoes, Asymptomatic, Microcephaly, Travel Advice, Zika Virus

\section{Introduction}

Global travel provides an avenue for exposing travellers to new cultures and ideas, thereby promoting a more global community. It also promotes global economy by encouraging spending and creating employment internationally. [4] For example, in 2014, 34.4 million travellers came to the UK and spent a record $£ 21.8$ billion. In the same year, 12.2 million UK residents travelled overseas and spent $£ 6.7$ billion compared to $£ 9.2$ billion in 2013. [5] As much as these statistics show that international travel is of immense value to the global economy, it has also been known to be a major means of transmitting diseases that pose risks to public health.

\subsection{Travel Risk Theory}

A large body of scholarly literature regarding travel risks has been developed; yet, there is no single widely accepted definition for risk. [6] [7] Risk is not a homogenous concept; it takes myriad of forms and is influenced by facts, perceptions, experience, social groups, culture, and personal judgments. [4] However, war and political instability; health concerns; natural disaster; crime and terrorism have been identified as the most critical travel risks' factors. Given the social and economic significance of travel, the effects of the above factors can potentially be devastating for the nations concerned. [4] One study has shown that when perceptions of risk are high, intentions to travel are lower and risk perceptions considerably influence the intention to travel or pivotal to the travel-related decision-making process. [8] In other words, when potential traveller perceives a travel destination as very risky, the traveller may modify his or her intention to travel to the perceived risky destination. The travel risk factors have notably informed travel advice issued by UK Government travel health organisations. [9] 


\subsection{Implication of Zika Virus Transmission on Travel Pattern}

Studies have shown that travel pattern influences disease outbreaks and exacerbate international spread of infectious diseases. Studies have also shown that the number of international flights, travel routes, aviation network, countries of departure and countries of destination, number of passengers carried, and size of aircraft are important considerations for potential infectious disease outbreak and transmission. The evidence from the studies shows that travellers arriving with infectious disease could create an outbreak or spread the disease through contact with individuals and groups in the host country. [4] [10] [11]. A recent report by WHO (2016), which was cited by CDC (2016) shows that the first local transmission of Zika virus in the Western Hemisphere was reported in May 2015; with locally acquired cases identified in Brazil. The local transmission had been identified in at least 14 countries or territories in the Americas as of January 15, 2016. [12]

Zika virus originated from Zika forest in Uganda where it got its name and was first isolated in 1947 from a febrile sentinel rhesus monkey found in the Zika forest. [13] According to Catherine Byaruhanga (2016), a BBC African reporter, Zika virus was discovered in the forest by Ugandan, American and European scientists. The forest was then the hub of scientific research in East Africa and while testing monkeys in the forest the scientists, whose research had been funded by the Rockefeller Foundation, accidentally came across a new microorganism, which they later named Zika. [14]

In Uganda where the virus was first discovered only two cases had been confirmed in the last seven decades. [15] We found this interesting but speculated that it may be due the lack of testing facilities for Zika virus especially in the rural areas with poor health facilities. For example, the Uganda Virus Research Institute is the only place in Uganda where Zika blood test can be carried out. [15] However, serological studies and isolation of the Zika virus strains have shown that the disease has a wide geographical distribution. [16] Since the 1960s, human cases of the Zika virus have been sporadically reported in Asia and Africa. The first large documented outbreak occurred in 2007 in Yap Island, Micronesia, in the North Pacific. [13] Marta Zaraska (2015) reporting for Washington post, Health and Sciences estimated that three-quarters out of 11,000 or so residents of the Yap Island older than 3 years, were infected by the Zika virus. The Island's residents that were infected showed common symptoms, which resolved within few days and none of the residents, died and until 2007 when scientists knew only fourteen properly documented human cases of the disease. [16]

In 2013, Zika showed up again in in Tahiti and other parts of French Polynesia; infecting an estimated 28,000 people, equals to about 11 per cent of the population of the islands. By 2014, the virus showed up in several South Pacific islands such as New Caledonia, east of Australia and the
Cook Islands. The disease popped up in the Easter Island and as the island is part of Chile, the arrival marks the first confirmed cases of the disease in the Americas. [16]

Zika showed up in Brazil in 2014 with only 150 cases, which is a very small number for its population. [12] The outbreak of the disease in May 2015 is unprecedented culminating in more than 1 million cases as well as 4,000 suspected cases of microcephaly, with 270 confirmed cases that health officials believe are linked to the Zika virus. [12] The Brazil Ministry of Health has since reported a remarkable increase in the number of babies born with microcephaly. However, it is not conclusive how the microcephaly cases are linked with Zika virus infection and what factors increase risk of the disease to the foetus. [12] [17] The former statement has been collaborated by the National Travel Health Network and Centre (NaTHNaC), the UK Department of Health's travel advice branch, when it reported that scientists are currently investigating whether a causal relationship exists between exposure to Zika virus in pregnancy and microcephaly. [18]

\subsection{Zika Virus Poses Health Risks for Travellers}

The clinical characteristic of Zika virus infection include acute onset of fever, joint pain, maculopapular rash, eye pain, itching, arthralgia, headache, muscle pain, conjunctivitis or red eyes. [12] [19] To confirm Zika virus infection, performance of RT-PCR is required on serum specimens collected within the first week of illness. After onset of the virus infection, Immunoglobulin $\mathrm{M}$ and neutralizing antibody testing should be performed on specimens collected $\geq 4$ days. However, the Zika virus IgM antibody assays can be positive due to antibodies against associated flavivirus such as dengue and yellow fever viruses. A virus-specific neutralization testing provides added specificity but might not discriminate between cross-reacting antibodies in people who have been previously infected with or vaccinated against the associated flavivirus. [12]

The Zika virus RNA has been identified in tissues from several infants with microcephaly and from foetal losses in women infected during pregnancy and the preliminary analysis of research carried out by Brazilian authorities following the current outbreak has established a relationship between an increase in cases of microcephaly in new-borns and Zika virus infections. [12] Microcephaly is a birth defect where a baby's head is smaller than expected when compared to babies of the same sex and age. The head circumference of babies with microcephaly is typically at or below 3 per cent on the growth curve. The babies often have smaller brains that might not have developed properly. Other microcephaly complications include seizures, hearing loss, vision problems; intellectual disability such as decreased ability to learn and function in daily life; developmental delay such as problems with speech or other developmental milestones like sitting, standing, and walking. These problems can range from mild to severe; often lifelong and in cases can be life-threatening. The numbers of new cases have 
been on the increase. Barchfield and Stobbe (2016) citing Brazil's Health Ministry reported suspected cases of microcephaly linked to Zika in 270 of 700 of the 4,180 cases they have tested since October 2015. [20] [21]

The greatest risk of birth defect that results from microcephaly appears to be associated with Zika virus infection during the first trimester of pregnancy. [20] Microcephaly has also been known to be the result of genetic or environmental factors such as toxicity and radiation. Other causes of microcephaly can include exposures during pregnancy to infections such as rubella, toxoplasmosis, or cytomegalovirus; lack of nutrients or not getting enough food culminating in severe malnutrition and exposure to harmful substances such as alcohol, certain drugs, or toxic chemicals. [20] Yet, the recent coverage of Zika virus has focused mainly on the possibility that Zika virus infection can lead to microcephaly complication including birth defects. Much as it is difficult to predict at birth what problems a baby will have from microcephaly, most babies with microcephaly generally need close follow-up through regular check-ups with a healthcare provider who will monitor their growth and development. [20] [22]

The transmission from Zika virus infected pregnant mother to her baby during pregnancy or around the time of birth is still unknown. According to Pan American Health Organization (PAHO), research is on-going to determine how some mothers can pass the virus to their babies. [22] Thus, until research evidence is conclusive, pregnant women should attend regular prenatal check-ups and receive whatever tests their health care providers deem necessary at each stage of pregnancy.

However, there is growing evidence that people infected with Zika virus will have no symptoms or fall ill; one in five of the people infected with the disease become symptomatic. [12] In other words, four out of five people infected with the Zika virus become asymptomatic. As a consequence, 80 per cent of the people infected with the virus will not seek treatment and those who come down with symptoms will have no treatment as there is no vaccine or drug to treat the disease as yet. [23] This has public health implication as people who are asymptomatic and those who are in the incubation period of Zika virus could potentially donate infected blood or exchange contaminated body fluid, thereby, making human to human transmission possible. [24]

The current treatment is generally supportive endeavour that include rest, fluids in-take, and pain management involving the use of analgesics and antipyretics. Public health experts, however, advised that those infected with the virus must not be given Aspirin and other non-steroidal anti-inflammatory drugs (NSAIDs). The abstention from the use of such drugs is to reduce the risk of haemorrhage. [12]

As allude earlier and supported by epidemiological study, Zika virus first emerged in Africa before spreading to Pacific Islands, Caribbean and now American countries. [14] [15] [19] The current outbreak in Brazil highlights the potential of the virus as an emerging pathogen. It is imperative, therefore, to explore how the disease is transmitted through travel.
One study demonstrated that Zika virus is transmitted to humans by mosquitoes, especially the Aedes aegypti species. [25] Aedes aegypti mosquito is one of the two mosquitoes (Aedes aegypti and Aedes albopictus) that spread dengue and chikungunya viruses. [26] The Zika virus is transmitted to an individual mostly through bites from an infected Aedes aegypti mosquito. The mosquito becomes infected when it feed on a person already infected with the virus and cannot be caught from coming into contact with the infected person. [27] In other words, the Zika virus natural transmission cycle involves Aedes aegypti mosquitoes, but sexual transmission has been suggested. [20] This probable sexual transmission took place after a patient who was infected with Zika virus in Senegal in 2008 returned to his home in Colorado, United States and experienced common symptoms of Zika virus infection with his wife. His wife had not travelled out of the United States during the previous year but had sexual intercourse with him a day after he returned home from Africa. [28]

The current spread of Zika virus in Caribbean Islands and the American countries constitutes a significant development in the epidemiology of this emerging vector-borne disease. [29] There is now enough compelling evidence to suggest that Zika virus spread from African to these countries through travel. For example, we alluded earlier that one person in Colorado became infected with the Zika virus after having sexual contact with her husband, who had returned from an African country where the virus is present [28] Although the man' wife tested positive to Zika virus, no effort was made to check if the virus was in the man's semen, which would be evidence of sexual transmission of Zika virus. [30] However, many people in the U.S state of Florida, Illinois, New Jersey, Texas, Arkansas and other several other states who recently travelled to countries where Zika virus is present have tested positive to the virus. This is in addition to the 20 confirmed cases of the virus in Puerto Rico and the U.S. Virgin Islands, bringing the total number of Zika virus in the United States to 51. [31] [32]

\subsection{Rationale for Study}

Since the start of the Zika virus outbreak in May 2015, five UK travellers have been diagnosed with the disease. This means that there is a real risk of increased Zika virus transmission in the UK through travel, yet there is an obvious absence of study on transmission through travel or measure of the effectiveness of current travel advice. [3] This study represents one of the first steps toward the exploration of travel-related Zika virus transmission and review of the nature of current travel advice to UK travellers.

\subsection{Aim of Study}

The aim of this study is to explore Zika virus travel-related transmission and carry out a review of current travel advice given to UK travellers aimed at minimising their health risks. 


\subsection{Objectives}

To review surveillance reports and travel advice published by the European Centre for Disease Prevention and Control (ECDC), United States Centers for Disease Control and Prevention (CDC), World Health Organization (WHO), Public Health England (PHE) and establish Zika virus epidemiological situation since the disease outbreak.

To review recent Zika virus outbreaks alerts and travel advice published by Public Health England (PHE), Fitfortravel, NHS Choices and any other UK travel organisations.

To raise awareness of the issues pertinent to Zika virus travel-related transmission and thereby increase efforts towards enhancing travel safety.

\section{Method}

This study was conducted using the literature review research method. The overall goal of this method is to provide a full picture of Zika virus travel related transmission which can be concealed for the health care professional offering travel advice when only one piece of report is viewed on its own. The literature for this review was gathered through searches on the Google Scholar, Google Chrome, Scopus, Medical Literature Online (MEDLINE) and the ProMED data bases using the keywords Aedesaegypti, dengue fever, yellow fever, microcephaly, vector, travel and Zika virus. Given that there is little or no research paper on the recent Zika virus outbreak, this study searched the following websites: European Centre for Disease Prevention and Control (ECDC), www.eurosurveillance.org/; United States Centers for Disease Control and Prevention (CDC), www.cdc.gov, and World Health Organisation (WHO), http://www.who.int/en/. The reports from these sources were reviewed for general information on the Zika epidemiological situation in the Pacific Islands, Caribbean, and the American countries. The Public Health England (PHE),

www.gov.uk/government/organisations/public-health-engla nd and Fitfortravel, www.fitfortravel.nhs.uk and NHS Choices, http://www.nhs.uk/pages/home.aspx websites were also searched for information on Zika virus outbreak alerts and travel advice for UK travellers.

\section{Result}

Some health experts' view of the recent Zika virus outbreak is that it could trigger global outbreak. [1] Contrary to this view, we found that the disease outbreak in UK is unlikely. This is because the condition necessary for Aedes aegypti mosquitoes to breed is not fully present in the UK. [33] The Aedes aegypti mosquito that produces Zika virus survives year round in tropical and subtropical climates; extremely common in areas lacking in pipe borne water systems, and depend greatly on water storage containers to lay their eggs. [18] A study published in the medical journal The Lancet, by a public health researcher Simon Hales and colleagues found that the mosquito-borne disease transmission is climate sensitive for several reasons. The mosquitoes require standing water to breed, and a warm ambient temperature is critical to adult feeding behaviour and mortality, the rate of larval development, and speed of virus replication. They posited that if the climate is too cold, viral development is slowed down and the mosquitoes are unlikely to survive long enough to become infectious. [34] A group of researchers, on the other hand, working for the UN Intergovernmental Panel on Climate Change analysed several research studies and found that vector-borne diseases have been moving into more northern latitudes in response to global warming. [35] Given current global warming, these findings seem to reinforce the health experts' view that present Zika virus outbreak could trigger global health threat. [33]

International travel is important for global cultural exchange and income generation. [4] Yet, we found clear evidence of well-established association between travels and the acquisition or transmission of infectious diseases. [10] We found that since the start of the Zika virus outbreak in May 2015, 5 UK travellers have been diagnosed with the disease and that between 2010 and 2014 for which data is available, an estimated 1.4 million UK citizens travelled to areas where Zika virus is prevalent. [3] The implication of this finding is that Aedes aegypti mosquito poses health risks to the thousands of UK resident who travel to Zika virus affected countries every year. There is also the likelihood of increase cases of the disease transmission in UK through travel. These potential risks may have prompted the UK Foreign Office to asked people who are travelling to countries where Zika virus is prevalent to seek travel advice. [36] The following themes emerged when we reviewed various travel advices published by the UK Government travel websites:

\subsection{Advice for Those Concerned about Contracting the Zika Virus}

The people whose travel is unavoidable to countries where Zika virus is prevalent, should be advised to take scrupulous insect bite avoidance measures, both during daytime and night time hours; especially during mid-morning and late afternoon to dusk, when the Aedes aegypti mosquito mosquitos are most active. [3] They should also be advised to use insect repellent that contains $\mathrm{N}$, N-diethyl-meta-toluamide (DEET) on exposed skin. The repellent is considered safe to use even if they are pregnant and could be applied to skin after sunscreen is used. They should also include sleeping under a mosquito net and wearing loose clothing that covers the arms and legs. [37] [38]

\subsection{Advice for Those Concerned about the Risks Zika Virus Poses in Pregnancy}


The US Centers for Disease Control and Prevention position is that all pregnant women should be advised to refrain from travelling to countries affected by Zika virus. This is based on the inconclusive evidence suggesting a link between Zika virus infection with microcephaly and other neurological disorders. [39] The UK National Health Services current position is that women who are pregnant or planning to become pregnant should be advised to discuss their travel plans with appropriate health care professional. [37] All women who are pregnant or have plans to become pregnant during impending travel to areas where Zika virus is prevalent, should be strongly advised to seek pre-travel advice so that an informed decision can be made on whether or not to change the travel plans. Women who are not pregnant should be advised to consider using contraception during travel and for 28 days on their return to avoid an unplanned pregnancy occurring. [40] Women who are not pregnant should be advised to seek information on methods of contraception from their GP or community sexual health clinic professionals. [37]

\subsection{Advice for Those Concerned about Visit to Zika Affected Area Whilst Pregnant}

The current evidence, though not conclusive, suggests that pregnant women who contract the virus during pregnancy may have an increased risk of giving birth to a baby with microcephaly. [20] The people who are concerned about trying to get pregnant and have a history of travel to the Zika virus affected countries should be advised to see their GP or midwife and mention their travel history even if they are feeling well. They should also be advised to take folic acid supplements for 28 days before trying to get pregnant. The people who are experiencing Zika virus symptoms either during or within two weeks of returning home should be advised to wait at least six months after full recovery before attempting to get pregnant. If they are already feeling unwell, they should be advised to wait at least 28 days after they return home from Zika virus affected country before trying to get pregnant. [37]

Those concerned about visit to Zika affected area whilst pregnant should be advised to have an antenatal check promptly on return home, even if they are feeling well. They should also be advised to seek immediate medical attention if they are feeling unwell whilst travelling or on their return. [38] Individual who are concerned about visit to Zika affected area whilst pregnant should be advised to see their GP or midwife and mention their travel history; within two weeks of returning to the UK. The GP or the midwife should discuss the risk with them and arrange an ultrasound scan to monitor growth of their baby. The GP or midwife may also make referral to a specialist foetal medicine service for monitoring or order for blood test if Zika virus infection is suspected. [37] Referral should also be made to a maternal-foetal medicine or infectious disease specialist with expertise in pregnancy management. Those pregnant with laboratory evidence of Zika virus in serum or amniotic fluid should include serial ultrasounds to monitor foetal anatomy and growth every 3-4 weeks. [39] As there is no known antiviral treatment for the Zika virus, those infected with the disease should be advice to expect treatments that are meant to manage the symptoms and not cure.

\subsection{Advice for Those Concerned about Sexual Transmission of Zika Virus}

We could not find evidence of reported case of sexual transmission of Zika virus in UK. The finding is in line with Public Health England deposition that the risk of such transmission to the UK is very low. [3] [41] Much as sexual transmission of Zika virus in UK is thought to be low, Zika virus has been known to be present in semen up to two weeks after recovery from the virus infection. [42] The evidence may have prompted the British Medical Association (BMA) to recommend that male partner arriving from Zika affected area should be advised to use condom if their female partner is at risk of getting pregnant, or is already pregnant; for the following durations:

- For 28 days after his return from a Zika virus affected area if he has not had any symptoms compatible with Zika virus infection. The 28 days represents an estimated 14 days incubation period plus an estimated 14 days period of viraemia.

- For 6 months following recovery if a clinical illness is compatible with Zika virus infection or laboratory-confirmed Zika virus infection was reported. [43]

Lastly, in the absence of research knowledge to ascertain clearly how Zika virus is transmitted from mother to unborn child [1] and through sexual intercourse, [41] the UK health care professionals offering travel advices should be checking on the National Travel Health Network and Centre for Zika virus transmission updates. Until more is known, current advices are temporary and likely to change as research evidence and more information becomes available.

\section{Discussion}

We found that the World Health Organisation's declaration of Zika virus as an important Public Health Emergency of International Concern (PHEIC) on $1^{\text {st }}$ of February 2016 is mainly driven by two hypothesis:

First, is based on the evidence of growing support for another hypothesis that increase cases of microcephaly found in new born babies is linked to the on-going Zika virus outbreak. [1] However, we could not find any conclusive evidence that Zika virus infection caused any of the abnormalities found in the babies with microcephaly. We also could not find any conclusive scientific evidence of full spectrum of outcomes that might be associated with the Zika virus infection during pregnancy or the factors that might increase risk of the disease infection to the foetus. However, a study published in The Lancet Medical Journal and reported in the Daily Mail Online, suggests that the risk of 
microcephaly associated with Zika virus infection is relatively low, amounting to one per cent in comparison to other maternal infections. [44] Contrary to this view, the findings of a recent study on retrospective analysis of a large Zika virus outbreak in French Polynesia in 2013-14, which was also published by the Lancet, strongly support the current suspected link between infection with Zika virus during pregnancy and microcephaly. [45] The authors of the former study, however, noted that the link remains an important public health issue, because the risk of Zika virus infection is particularly high during the current outbreaks in Brazil. [44] Whilst, the authors of the later study emphasise the need for health authorities of affected countries to organise public health activities involving foetal monitoring, promote vector control, and provide evidence-driven information for pregnant women. [45]

The second hypothesis is based on the view that Zika virus outbreak constitutes a health risk to other countries through international spread. International travel provides an avenue for exposing travellers to new cultures and ideas; thereby promoting a more global community. It also promotes global economy by encouraging spending and creating employment internationally. [12] For example, in 2014, 34.4 million travellers came to the UK and spent a record $£ 21.8$ billion. In the same year, 12.2 million UK residents travelled overseas and spent $£ 6.7$ billion compared to $£ 9.2$ billion in 2013. [13] These statistics show that international travel is of immense value to the global economy, but yet has been known to be a major means of transmitting diseases that pose risks to public health. The SARS outbreak in 2003 and West African Ebola virus outbreak in 2014 exemplifies outbreaks associated to international travels. [4] [11]. Similarly, Zika virus that originated in Uganda in 1947 is now transmitted in at least 14 countries or territories in the Americas as at January 15, 2016. [12]

However, we could not establish the true extent of the Zika virus spread with certainty, since most of the affected countries have not been conducting appropriate surveillance. In the past, cases of the disease have been reported in Africa, Asia and the Pacific Islands. The current report has shown spread far beyond the affected areas where dozens of cases have been identified among travellers. [44] It has been reported recently in the media that airlines and cruise operators, hotels and tour operators serving Latin America and the Caribbean are facing growing concern among travellers spooked by the mosquito-borne Zika virus. [47] In addition, we found evidence of media reports, highlighting the possibility of Zika virus outbreak in UK through travel. For example, Dr Nick Beeching, a tropical medicine consultant at the Royal Liverpool Hospital was quoted by UK Daily Mail Online as saying that the risk of transmitting the disease in UK is so high because South America has become an increasingly popular tourist destination for UK travellers. [47] Similarly, Lizzie Dearden reporting for the UK Independent echoed health experts warning that Europe should be prepared for the virus to spread through the continent in the summer due to traveller returning from the

\section{Zika virus affected countries. [48]}

We found these warnings as important public health issue and were taken seriously by UK and indeed European policy makers. [48] We also found that this is because of a well-established evidence of association between travels and the acquisition or transmission of infectious diseases. [10] For example, this review found 31 reported cases of travel-associated Zika virus in 11 states in the United States of America and the District of Columbia, from the period of outbreak in May 2015 to the present. [49] [50] In the UK, there are 5 cases of travellers diagnosed with the Zika virus since the start of the outbreak [3]

In response to the threat pose by the Zika virus, the Public Health England requires all healthcare professionals to consider Zika virus among the differential diagnoses of patients with fever returning from endemic areas. If a case of Zika virus is suspected, the healthcare professionals should take appropriate blood samples and send for testing together with a full travel and clinical history with relevant dates to the PHE Rare and Imported Pathogens Laboratory as early as possible. They should also be vigilant for any increase of neurological and autoimmune syndromes in both adults and children - or congenital malformations in new born infants where the cause is not otherwise evident in patients with a history of travel to Zika virus endemic areas. [51] The UK Foreign Office has asked UK travellers to and from Zika virus affected areas to seek travel advice from qualified healthcare professional. [36]

Finally, there are many unanswered questions when we examined the evidence of how Zika virus is transmitted through sexual intercourse. We review evidence from two studies, which found Zika virus RNA in semen and one study, which found replicable Zika virus particles in semen more than three weeks after the onset of Zika symptoms. We could not find any conclusive evidence when the studies were analysed that could explain whether or not the men infected with the Zika virus can transmit the disease to their sex partners. The limited evidence suggests that sexual transmission of Zika virus through semen is possible but that these events are rare. [29] Thus, the WHO recent announcement that it plans to fund research into Zika virus transmission is a welcome development. [1]

\section{Limitation of Study}

The aim of this study is only partially achieved because the reports that form the basis of the travel advices found and discussed in this study are not conclusive. For example, experts are yet to be fully convinced of the risks Zika virus transmission from pregnant woman to her unborn child and also transmission via sexual intercourse. [28] [38] [41] Further studies are therefore required to clarify the risks of Zika virus transmission during pregnancy and transmission through sexual intercourse. Until more is known, the only sensible advice is to avoid mosquitoes' bite.

In addition, this study could not establish the true extent of 
the Zika virus transmission with certainty, since most of the affected countries have not been conducting appropriate surveillance. In other words, there are many countries where the Zika virus transmission is on-going but difficult to ascertain because there is no surveillance data. [48] This probably explains why the Public Health England and other public health organisations are updating their travel notices and surveillance reports as information becomes available. [43] [50] [52]. Thus, the current travel advices alluded earlier are momentary and likely to change as more information becomes available.

Finally, these limitations notwithstanding, this study has provided useful findings, given that there is so much we do not know about the Zika virus. We now have clear evidence that there is a real risk of Zika virus transmission in UK through travel. With the increase spreading of the disease in the holiday destination for many UK residents (Caribbean Islands and American countries), we can confidently make two predictions; first is that the number of the disease cases among travellers visiting or returning from the areas is likely to increase and second is that the disease transmission to UK through travel could increase in future due to global warming but the risk of full outbreak may be low.

\section{Conclusions}

The finding of this study shows that Zika virus is already transmitted in UK through travel and could spread in future due to global warming but the risk of full outbreak is low. [3]The study, on the other hand, could not find answers to many questions when it comes to how the Zika virus is transmitted sexually. [20] We could not also find conclusive evidence of the risks Zika virus transmission from a pregnant woman to her unborn child. We therefore support the view that studies should be planned to learn more about the risks of Zika virus transmission. [1] Until more is known, current travel advices are momentary and likely to change as more information becomes available. Thus, we recommend that healthcare professionals offering travel advice should be checking on the National Travel Health Network and Centre to stay abreast of the latest Zika virus updates.

Finally, additional research will be required to establish whether or not other mosquito species are involved in the current Zika virus outbreak. A recent study published by the medical journal, The Lancet warned that to assume that Aedes aegypti is the only mosquito involved in Zika virus transmission in areas where other mosquito species coexist is naive, and could be catastrophic if other species are found to have important roles in Zika virus transmission. Therefore, to minimise the drastic effects of Zika virus disease outbreaks, researchers working on vector pathogen interactions must attempt to find out whether or not other types of mosquitoes are involved in the virus transmission. [52]

\section{Author's contributions}

VI is an academic who provided scholarship for the study and wrote most part of the script. CI is a nurse practitioner and wrote part of the script pertaining to travel advice. VI and CI read and critically revised the first draft as well as the subsequent drafts and jointly approved the final script.

\section{REFERENCES}

[1] WHO (2016), WHO Director-General summarizes the outcome of the Emergency Committee regarding clusters of microcephaly and Guillain-Barré syndrome, http:/www.who.int/mediacentre/news/statements/2016/emer gency-committee-zika-microcephaly/en/ (Online access, February 2016)

[2] Daily Mail Online (2016), Zika set to hit the UK: Cases of 'head shrinking' virus are 'highly likely' as travellers return home from Latin America, doctor warns http://www.dailymail.co.uk/health/article-3430116/Zika-sethit-UK-Cases-head-shrinking-virus-highly-likely-travellers-r eturn-home-Latin-America-doctor-claims.html (Online access, February 2016)

[3] PHE (2016), Zika virus: travel advice for pregnant women, https://www.gov.uk/government/news/zika-virus-travel-advi ce-for-pregnant-women (Online access, February 2016)

[4] Baker, D. (2016), Tourism and the Health Effects of Infectious Diseases: Are There Potential Risks for Tourists? http://www.palermo.edu/Archivos content/2015/economicas /journal-tourism/edicion12/03_Tourism_and_Infectous_Dise ase.pdf

[5] Office of National Statistics (2016), Travel trends: 2014 http://www.ons.gov.uk/peoplepopulationandcommunity/leis ureandtourism/articles/traveltrends/2015-05-20\#uk-residents -visits-abroad

[6] Dwyer, L. (2002). Economic contribution of convention tourism: Conceptual and empirical issues. In Karin Weber and Kye-Sung Chon (eds), Convention tourism. International research and industry perspectives (pp. 21-35). New York: Haworth Hospitality Press

[7] Faro, David, Rottenstreich, Yuval. (2006). Affect, empathy, and regressive mispredictions of others' preferences under risk. Management Science, 52(4), 529-541.

[8] Allen, J., O'Toole, W., McDonnell, I., \& Harris, R. (2002).Festival and special event management, 2nd edition. Australia: John Wiley \& Sons Australia, Ltd.

[9] Reisinger, Y., and Mavondo, F. (2005). Travelanxiety and intentions to travelinternationally: Implications of travelrisk perception. Journal of TravelResearch, 43(3), 212-225.

[10] Wilson, M.E. (2003). The traveller and emerging infections: sentinel, courier, transmitter. Journal of Applied Microbiology, 94:1S-11S.

[11] Icheku, V. (2015), Assessment of the Potential for Spread of Deadly Ebola Virus Across International Borders by Returnee Travellers and Humanitarian Health Workers from West Africa, Universal Journal of Public Health 3(1): 28-40, 2015 
DOI: $\quad$ 10.13189/ujph.2015.030105, http://www.hrpub.org (Online access, February 2016)

[12] CDC (2016), Recognizing, Managing, and Reporting Zika Virus Infections in Travellers Returning from Central America, South America, the Caribbean, and Mexico, The Centers for Disease Control and Prevention, Health Alert Network, http://emergency.cdc.gov/han/han00385.asp (Online access, February 2016)

[13] Besnard M, Lastere S, Teissier A, Cao-Lormeau VM, Musso D. Evidence of perinatal transmission of Zika virus, French Polynesia, December 2013 and February 2014 .Euro Surveillance. 2014; 19(13): pii=20751. Available online: http://www.eurosurveillance.org/ViewArticle.aspx?ArticleId $=20751$ (Online access, January 2016)

[14] Byaruhanga, C. (2016), Zika virus: Inside Uganda's forest where the disease originates, http://www.bbc.co.uk/news/wo rld-africa-35431181 (Online access, February 2016)

[15] Kutsuna S, Kato Y, Takasaki T, Moi ML, Kotaki A, Uemura H, Matono T, Fujiya Y, Mawatari M, Takeshita N, Hayakawa K, Kanagawa S, Ohmagari N.(2014) Two cases of Zika fever imported from French Polynesia to Japan, December 2013 to January 2014. Euro Surveillance. 2014; 19(4): pii=20683. http://www.eurosurveillance.org/ViewArticle.aspx?ArticleId $=20683$ (Online access, January 2016)

[16] Zaraska, M. (2015), Bumpy rash, achy joints, inflamed eyes? There's a new disease in town, Washington Post https://www.washingtonpost.com/national/health-science/bu mpy-rash-achy-joints-inflamed-eyes-theres-a-new-disease-in -town/2015/09/21/417a89f4-3086-11e5-8353-1215475949f4 _story.html (Online access, January 2016)

[17] Gallagher, J., (2016), Zika outbreak: The mosquito menace, BBC News Online, http://www.bbc.co.uk/news/health-3542 7491 (Online access, February 2016)

[18] Wallwork, E. (2016), Zika Virus: Pregnant Women Advised to Reconsider Travel to Brazil and 14 Other Countries, the Huffington Post UK, 22nd January, 2016, http://www.huffin gtonpost.co.uk/2016/01/22/zika-virus-pregnant-women-trave 1-advice_n_9048724.html (Online access, February 2016)

[19] Tappe D, Rissland J, Gabriel M, Emmerich P, Gunther S, Held G, Smola S, Schmidt-Chanasit J.(2014), First case of laboratory-confirmed Zika virus infection imported into Europe, November 2013. Euro Surveillance. 2014;19(4): pii $=20685$

http://www.eurosurveillance.org/ViewArticle.aspx?ArticleId $=20685$ (Online access, January 2016)

[20] CDC (2016), Facts about Microcephaly, http://www.cdc.gov /ncbddd/birthdefects/microcephaly.html (Online access, February 2016)

[21] Barchfield, J. and Stobbe, M. (2016), Question and Answers: Zika and pregnancy $\square$

http://www.paho.org/hq/index.php?option=com_content\&vi ew $=$ article $\& i d=11552 \% 3$ Aquestion-and-answers-zika-and-p regnancy\&catid $=8424 \% 3$ Acontent\&Itemid $=41711$ \&lang $=$ en (Online access, February 2016)

[22] PAHO (2016), Question and Answers: Zika and pregnancy, Pan American Health Organization http://www.paho.org/hq/i ndex.php?option $=$ com_content $\&$ view $=$ article $\&$ id $=11552 \% 3$ Aquestion-and-answers-zika-and-pregnancy \& catid $=8424 \% 3$ Acontent\&Itemid=41711\&lang=en (Online access, February 2016)
[23] Swanson, W., S. (2016), Scared about Zika virus? Here are some answers that you need to know, http://www.kevinmd.com/blog/2016/01/scared-about-zika-vi rus-here-are-some-answers-that-you-need-to-know.html (Online access, February 2016)

[24] ECDC (2014), Special edition: Chikungunya and Zika virus October $2014 \mathrm{http} / /$ www.eurosurveillance.org/images/dyna mic/ET/V19N02/V19N02.pdf (Online access, January 2016)

[25] Duffy, M.R., Chen, T.H., Hancock, W.T., Powers, A.M., Kool, J.L., Lanciotti, R.S., (2009) Zika virus outbreak on Yap Island, Federated States of Micronesia. N Engl J Med. 2009 Jun 11;360(24):2536-43.

[26] CDC (2016), Dengue and the Aedes aegypti mosquito, Centers for Disease Control and Prevention http://www.cdc.gov/dengue/resources/30Jan2012/aegyptifact sheet.pdf (Online access, February 2016)

[27] Hayes, E.B. (2009) Zika virus outside Africa, Emerging Infectious Diseases, 2009;15:1347-50

[28] Musso, D., Roche, C., Robin, E., Nhan, T., Teissier, A., Cao-Lormeau, V.M. (2015), Potential sexual transmission of Zika virus. Emerg Infect Dis. Feb; 21 (2):359-61. http://wwwnc.cdc.gov/eid/article/21/2/14-1363 article (Online access, February 2016)

[29] ECDC (2016) Rapid risk assessment: Zika virus disease epidemic - European Centre for Disease Prevention and Control, Stockholm, http://ecdc.europa.eu/en/publications/Pu blications/zika-virus-rapid-risk-assessment-8-february-2016. pdf (Online access, February 2016)

[30] Lowes, R., (2016), Sexual Transmission of Zika Virus Reported in Texas, Medscape Medical News, http://www.me dscape.com/viewarticle/858206 (Online access, February 2016)

[31] NDTV (2016), what you need to know about the Zika Virus, http://www.ndtv.com/health/what-you-need-to-know-about-t he-zika-virus-1271245 (Online access, February 2016)

[32] Westcott, L. (2016), Where in the U.S. have Zika cases been reported? Newsweek ON 1/27/16 AT 9:15 PM, http://europe.newsweek.com/zika-cases-america-420343 (Online access, February 2016)

[33] The Observer (2016), Zika virus could be bigger global health threat than Ebola, say health experts, The Observer Online, $30^{\text {th }}$ January, http://www.theguardian.com/world/2016/jan/3 0/zika-virus-health-fears (Online access, February 2016)

[34] Simon Hales, Neil de Wet, John Maindonald, Woodward, A. (2002), Potential effect of population and climate changes on global distribution of dengue fever: an empirical model, Lancet 2002; 360: 830-34. http://www.bvsde.paho.org/bvsas v/fulltext/potential.pdf (Online access, February 2016)

[35] Confalonieri, U., B. Menne, R. Akhtar, K.L. Ebi, M. Hauengue, R.S. Kovats, B. Revich and Woodward, A. (2007): Human health. Climate Change 2007: Impacts, Adaptation and Vulnerability. Contribution of Working Group II to the Fourth Assessment Report of the Intergovernmental Panel on Climate Change, M.L. Parry, O.F. Canziani, J.P. Palutikof, P.J. van der Linden and C.E. Hanson, Eds., Cambridge University Press, Cambridge, UK, 391-431.

[36] UK Foreign Office (2016), foreign travel advice: Brazil, https://www.gov.uk/foreign-travel-advice/brazil (Online 
access, February 2016)

[37] NHS Choices (2016), Zika virus: your questions answered, http://www.nhs.uk/news/2016/01January/Pages/Zika-virus-y our-questions-answered.aspx (Online access, March 2016)

[38] Fitfortravel (2016), Microcephaly in Brazil (Update), http://www.fitfortravel.nhs.uk/news/newsdetail.aspx?Id=214 27 (Online access, March 2016)

[39] Petersen, E.E, Staples, J.E, Meaney-Delman, D. (2016); Interim guidelines for pregnant women during a Zika virus outbreak-United States, 2016. MMWR Morbidity and Mortality Weekly Report. 2016; 65: 30-33, http://www.cdc. gov/mmwr/volumes/65/wr/mm6502e1.htm (Online access, March 2016)

[40] Fitfortravel. NHS. (2016) Zika Virus Infection $\mathrm{http}: / / w w w . f i t f o r t r a v e l . n h s . u k / a d v i c e / d i s e a s e-p r e v e n t i o n-a d v$ ice/zika-virus-infection.aspx (Online access, February 2016)

[41] Foy, B.D., Kobylinski , K.C., Chilson Foy, J.L., Blitvich, B.J., Travassos da Rosa, A., Haddow, A.D, (2011), al. Probable non-vector-borne transmission of Zika virus, Colorado, USA. Emerg Infect Dis. 2011 May; 17(5):880-2.

[42] Travel Health Pro (2016) (2016) Zika virus - update and advice for pregnant women, Travel Health Pro is the website comprising the travel health resources of the National Travel Health Network and Centre (NaTHNaC).http://travelhealthpr o.org.uk/zika-virus-update-and-advice-for-pregnant-women/ (Online access, February 2016)

[43] BMA (2016), GP Practices: Zika virus infection guidance, The British Medical Association (BMA) http://www.bma.org.uk/support-at-work/gp-practices/service -provision/zika-virus-infection (Online access, March 2016)

[44] Parry, L. (2016) Yet more evidence of a 'strong' link between the Zika virus and microcephaly, experts warn, Dailymail Online, published: 23:30, 15 March 2016, http://www.dailymail.co.uk/health/article-3494140/Yet-evid ence-strong-link-Zika-virus-microcephaly-experts-warn.html (Online access, March 2016)

[45] Cauchemez, S., Besnard, M., Bompard, P.,Dub, T., Guillemette-Artur, P. Eyrolle-Guignot, D., Salje, H., Van Kerkhove, M.D., Abadie, V., Garel, C.,Fontanet, A., Mallet, H.,(2016) Association between Zika virus and microcephaly in French Polynesia, 2013-15: a retrospective study, http://www.thelancet.com/journals/lancet/article/PIIS 0140-6736(16)00651-6/fulltext (Online access, March 2016)

[46] Fares, $M$ and Tennery, A (2016)Travel Industry Faces Growing Concern Over Zika Virus, http://www.medscape.co $\mathrm{m} /$ viewarticle $/ 857805$ ?nlid $=98643 \quad 1842 \& \mathrm{src}=\mathrm{WNL}$ mdplsf eat 160202 mscpedit_wir\&uac $=1 \overline{4} 1873 \mathrm{MZ} \&$ spon $=\overline{17}$ \&imp 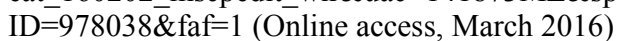

[47] Mail Online (2016, Zika set to hit the UK: Cases of 'head shrinking' virus are 'highly likely' as travellers return home from Latin America, doctor warns http://www.dailymail.co.u k/health/article-3430116/Zika-set-hit-UK-Cases-head-shrink ing-virus-highly-likely-travellers-return-home-Latin-Americ a-doctor-claims.html (Online access, February 2016)

[48] Dearden, L. (2016) Zika virus: What is it, what does it cause and how bad can it get? The independent, Thursday 4 February 2016, http://www.independent.co.uk/life-style/heal th-and-families/health-news/zika-virus-uk-america-europe-s ymptoms-cure-pregnant-women-microcephaly-a6851126.ht $\mathrm{ml}$ (Online access, March 2016)

[49] CDC (2016), CDC issues interim travel guidance related to Zika virus for 14 Countries and Territories in Central and South America and the Caribbean, http://www.cdc.gov/media/releases/2016/s0315zika-virus-tra vel.html (Online access, February 2016)

[50] CDC (2016), Transcript for CDC Telebriefing: Zika Virus Travel Alerthttp://www.cdc.gov/media/releases/2016/t0128zika-virus-101.html (Online access, February 2016)

[51] PHE (2016), Health Protection Report: Weekly Report, Volume 10 Numbers 1/2/3 Published on: 8, 15 and 22 January 2016,https://www.gov.uk/government/uploads/system/uploa ds/attachment_data/file/494969/hpr01-0316.pdf (Online access, January 2016)

[52] ECDC (2015) Factsheet for health professionals: Zika virus infection [Internet]. European Centre for Disease Prevention and Control, Stockholm, http://ecdc.europa.eu/en/healthtopic s/zika_virus_infection/factsheet-health-professionals/Pages/f actsheet_health_professionals.aspx. (Online access, February 2016)

[53] Ayres, C. F. J., (2016), Identification of Zika virus vectors and implications for control, Lancet, Published Online: 04 February $2016 \mathrm{http}: / /$ www.thelancet.com/journals/laninf/arti cle/PIIS1473-3099(16)00073-6/abstract (Online access, March 2016) 